\title{
Hubungan Jumlah Limfosit Plasma Biru dengan Spektrum Klinis dan Perannya dalam Mem- prediksi Perubahan Spektrum Klinis Infeksi Dengue pada Anak
}

\author{
Dewi Mulyani Irianti, Lelani Reniarti, Azhali MS \\ Bagian Ilmu Kesehatan Anak Fakultas Kedokteran Universitas Padjadjaran/RS Dr. Hasan Sadikin Bandung
}

\begin{abstract}
Latar belakang. Infeksi dengue mempunyai spektrum klinis yang luas. Limfosit plasma biru (LPB) sebagai respons imun selular yang khas pada infeksi dengue, berpotensi untuk digunakan sebagai prediktor perjalanan klinis infeksi dengue.

Tujuan. Untuk mengetahui hubungan jumlah LPB dengan perjalanan klinis infeksi dengue dan mengetahui peran LPB dalam memprediksi perubahan klinis infeksi dengue pada anak.

Metode. Dilakukan penelitian comparative longitudinal study di Bagian Ilmu Kesehatan Anak RS dr. Hasan Sadikin Bandung pada September-November 2007. Pasien anak umur kurang dari 14 tahun yang memenuhi kriteria klinis demam dengue (DD), demam berdarah dengue (DBD), dan sindrom syok dengue (SSD) menurut WHO (1997) disertai bukti infeksi dengue secara serologis dipilih secara konsekutif dan pemeriksaan LPB dilakukan pada saat kedatangan, dilanjutkan pada hari ke-5, ke-6, dan ke-7 sakit. Analisis statistik dilakukan dengan uji ANOVA, ratio correlation $\eta$ (eta), dan penghitungan odds ratio.

Hasil. Didapatkan 66 anak dengan diagnosis awal 43 pasien DD, 2 DBD, dan 21 SSD. Selanjutnya 20 pasien DD berubah menjadi DBD. Rata-rata jumlah LPB pasien DD, DBD, dan SSD berturut-turut adalah 4,$3 ; 9,1$; dan 16,4; dengan perbedaan yang bermakna $(p=0,000)$. Pasien yang mengalami perubahan tipe klinis memiliki jumlah LPB saat kedatangan lebih tinggi dari yang tidak mengalami perubahan, dengan cut off point $\geq 6 \mathrm{LPB}$ per 100 leukosit $(p=0,000$ dan $\mathrm{OR}=2,096)$.

Kesimpulan. Terdapat hubungan antara jumlah LPB dan perjalanan klinis infeksi dengue, semakin berat keadaan klinis semakin tinggi jumlah LPB. Jumlah LPB saat kedatangan pasien berobat dapat dijadikan prediktor perubahan klinis.(Sari Pediatri 2009;10(5):325-30).
\end{abstract}

Kata kunci: limfosit plasma biru, perjalanan klinis infeksi dengue, anak

\footnotetext{
Alamat Korespondensi:

Dr. Dewi Mulyani, Sp.A. M.kes, Bagian Ilmu Kesehatan Anak Fakultas Kedokteran Universitas Padjadjaran/Rumah Sakit Dr. Hasan Sadikin Jl. Pasteur No. 38 Bandung 40163, Indonesia. Telp. 022-2035957. E-mail: mulyani_dewi@yahoo.com
} 
$\mathrm{P}$ enyakit infeksi dengue merupakan masalah kesehatan di daerah tropis sedunia. ${ }^{1}$ Jumlah kasus infeksi dengue yang dilaporkan kepada the World Health Organization (WHO) meningkat tiap tahunnya. Kejadian luar biasa (KLB) dengue di Indonesia tahun 2004 telah menyebabkan 58.301 kasus dengan case fatality rate (CFR) 1,1\%.-4 Infeksi virus dengue memiliki spektrum klinis yang sangat luas. World Health Organization (WHO) membagi klinis yang bervariasi antara penyakit paling ringan (mild undifferentiated febrile illness), demam dengue, demam berdarah dengue, dan sindrom syok dengue. ${ }^{5,6}$

Perubahan imunologik pada infeksi dengue terdiri atas perubahan imunologik humoral dan selular. ${ }^{7-11}$ Perubahan humoral dapat dibuktikan dengan terbentuknya antibodi $\operatorname{IgG}$ dan IgM yang dapat dideteksi dengan pemeriksaan serologis. ${ }^{8-10}$ Beberapa peneliti menilai perubahan respons imun selular dengan ditemukan limfosit atipik yang khas untuk infeksi dengue, yaitu LPB yang bermanfaat sebagai alat bantu diagnosis dini dengan sensitivitas dan spesifisitas yang cukup tinggi. ${ }^{12-14}$ Infeksi virus dengue menyebabkan aktivasi sistem imun. Gangguan respons imun seperti inversi rasio CD4/CD8 tidak hanya mengganggu kemampuan sistem imun untuk membersihkan virus, tetapi juga menyebabkan produksi sitokin berlebih yang akan mempengaruhi limfosit $T$ untuk berdiferensiasi menjadi limfosit atipik khususnya LPB. ${ }^{6,11,15}$

Mengingat morbiditas yang cukup tinggi dan spektrum klinis yang luas serta sering disertai komplikasi berat, maka dilakukan penelitian untuk mengetahui hubungan jumlah LPB dengan spektrum klinis infeksi dengue dan juga ingin mengetahui peran LPB dalam memprediksi perubahan perjalanan klinis infeksi dengue.

\section{Metode}

Telah dilakukan penelitian prospektif comparative longitudinal study, pada bulan September-November 2007. Subjek dipilih secara konsekutif dari anak yang menderita infeksi dengue yang berobat ke Bagian/SMF Ilmu Kesehatan Anak RS Dr. Hasan Sadikin setelah mendapat informed consent dari orangtua. Kriteria inklusi anak umur $\leq 14$ tahun dan memenuhi kriteria klinis DD, DBD, dan SSD menurut WHO (1997) disertai uji serologis sebagai bukti infeksi dengue. Kriteria Subjek yang juga menderita penyakit infeksi lain tidak diikutsertakan dalam penelitian. Dengan batas kemaknaan 5\% dan power test $80 \%$ didapatkan besar sampel 20 pasien untuk masing-masing kelompok, sehingga jumlah sampel minimal adalah 60. Pada subjek dilakukan anamnesis, pemeriksaan fisis, dan pengambilan darah vena untuk pemeriksaan LPB yang dilakukan saat kedatangan di rumah sakit, dan secara periodik pada hari sakit ke-5, 6, dan 7. Kriteria klinis DD sesuai dengan kriteria klinis DBD menurut WHO tanpa disertai adanya hemokonsentrasi/peningkatan hematokrit $\geq 20 \%$ atau bukti kebocoran plasma. Diagnosis DBD apabila ditemukan dua kriteria klinis ditambah satu kriteria laboratorium (sedikitnya terdapat peningkatan hematokrit) berupa demam atau riwayat demam mendadak selama 2-7 hari, tendensi perdarahan, trombositopenia $(\leq 100.000 /$ $\mathrm{mm}^{3}$ ), dan terjadi kebocoran plasma. Kriteria SSD apabila ditemukan kriteria klinis DBD ditambah dengan kegagalan sirkulasi. Adanya infeksi dengue dibuktikan secara serologis apabila hasil IgM dan atau IgG antidengue positif. ${ }^{16}$

Cara pengecatan sediaan darah tepi berdasar WHO-DANIDA (1985) dengan Giemsa. Pemeriksaan hitung jenis leukosit dan LPB dilakukan oleh seorang pegawai laboratorium yang terlatih tanpa mengetahui asal sediaan. Jumlah LPB dihitung per 100 leukosit. Limfosit plasma biru adalah limfosit dengan sitoplasma biru tua dan berukuran lebih besar. Sitoplasma lebar dengan vakuolisasi halus sampai sangat nyata, dan dijumpai daerah perinuklear yang jernih. Inti terletak pada salah satu tepi sel, berbentuk bulat oval atau berbentuk ginjal. Kromatin inti kasar dan kadangkadang di dalam inti terdapat nukleoli. Pada sitoplasma tidak ada granula azurofilik. Daerah yang berdekatan dengan eritrosit tidak melekuk dan tidak bertambah biru. ${ }^{6}$

Untuk mengetahui adanya perbedaan LPB di antara spektrum klinis dengue digunakan uji ANOVA. Untuk melihat letak perbedaannya dipakai uji analisis dengan multiple comparison. Selanjutnya untuk mengetahui apakah terdapat hubungan antara LPB dan spektrum klinis infeksi dengue digunakan uji ratio correlation $\eta$ (eta). Untuk menilai kekuatan hubungan yang terjadi apakah termasuk ke dalam kategori kuat atau lemah digunakan klasifikasi Guilford. Dilakukan pengamatan pasien DD atau 
DBD yang mengalami perubahan perjalanan klinis, apakah memiliki jumlah LPB pada saat kedatangan lebih tinggi daripada pasien yang tidak mengalami perubahan secara klinis. Risiko terjadinya perubahan spektrum klinis berdasarkan jumlah LPB pada saat datang dihitung dengan odds ratio. Selanjutnya ditentukan cut off point jumlah LPB pada kasus yang mengalami perubahan perjalanan klinis dengan menggunakan kurva ROC.

\section{Hasil}

Selama kurun waktu penelitian, didapatkan 69 anak yang memenuhi kriteria klinis DD, DBD, dan SSD. Namun hanya 66 anak memenuhi kriteria inklusi penelitian, sedangkan tiga anak lainnya tidak diikutkan ke dalam penelitian dengan alasan satu anak tidak terbukti menderita infeksi dengue secara serologis dan dua anak menderita koinfeksi dengan demam tifoid. Karakteristik umum subjek penelitian tertera pada Tabel 1.

Dari 66 anak yang masuk kriteria penelitian terdiri dari $27(40,9 \%)$ anak perempuan dan 39 $(59 \%)$ anak laki-laki, dengan rentang umur antara 6 bulan-14 tahun. Berdasarkan penggolongan umur, subjek didominasi oleh anak berumur 6-10 tahun, $36(54,5 \%)$, selanjutnya kelompok umur $0-5$ tahun
$21(31,8 \%)$, dan kelompok 11-14 tahun $9(13,6 \%)$. Dalam perjalanan klinis, pada saat datang subjek penelitian dikelompokkan 43 pasien DD, 2 DBD,

Tabel 1. Karakteristik umum subjek penelitian

\begin{tabular}{|c|c|c|c|}
\hline \multirow{3}{*}{ Karakteristik subjek } & \multicolumn{3}{|c|}{ Spektrum klinis } \\
\hline & $\mathrm{DD}$ & $\mathrm{DBD}$ & SSD \\
\hline & $\mathrm{n}=23$ & $\mathrm{n}=22$ & $\mathrm{n}=21$ \\
\hline \multicolumn{4}{|l|}{ Jenis kelamin (n, \%) } \\
\hline Laki-laki & $13(19,7)$ & $14(21,2)$ & $12(18,2)$ \\
\hline Perempuan & $10(15,1)$ & $8(12,1)$ & $9(13,6)$ \\
\hline \multicolumn{4}{|l|}{ Umur (tahun, n, \%) } \\
\hline $0-5$ & $8(12,1)$ & $8(12,1)$ & $5(7,6)$ \\
\hline $6-10$ & $13(19,7)$ & $11(16,7)$ & $12(18,2)$ \\
\hline $11-14$ & $2(3)$ & $3(4,5)$ & $4(6,1)$ \\
\hline \multicolumn{4}{|c|}{ Hari sakit di rumah $(n, \%)$} \\
\hline $2-3$ & $5(7,6)$ & $3(4,5)$ & $0(0)$ \\
\hline $4-5$ & $15(22,7)$ & $16(24,2))$ & $13(19,7)$ \\
\hline $6-7$ & $3(4,5)$ & $3(4,5)$ & $8(12,1)$ \\
\hline \multicolumn{4}{|c|}{ Uji Rumple Leede (n, \%) } \\
\hline Positif & $16(24,2)$ & $21(31,8)$ & $6(9,1)$ \\
\hline Negatif & $7(10,6)$ & $1(1,5)$ & $15(22,7)$ \\
\hline \multicolumn{4}{|l|}{$\operatorname{IgG}(\mathrm{n}, \%)$} \\
\hline Positif & $17(25,8)$ & $17(25,8)$ & $20(30,3)$ \\
\hline Negatif & $6(9,1)$ & $5(7,6)$ & $1(1,5)$ \\
\hline \multicolumn{4}{|l|}{$\operatorname{IgM}(\mathrm{n}, \%)$} \\
\hline Positif & $18(27,3)$ & $18(27,3)$ & $21(31,8)$ \\
\hline Negatif & $5(7,6)$ & $4(6,1)$ & $0(0)$ \\
\hline
\end{tabular}

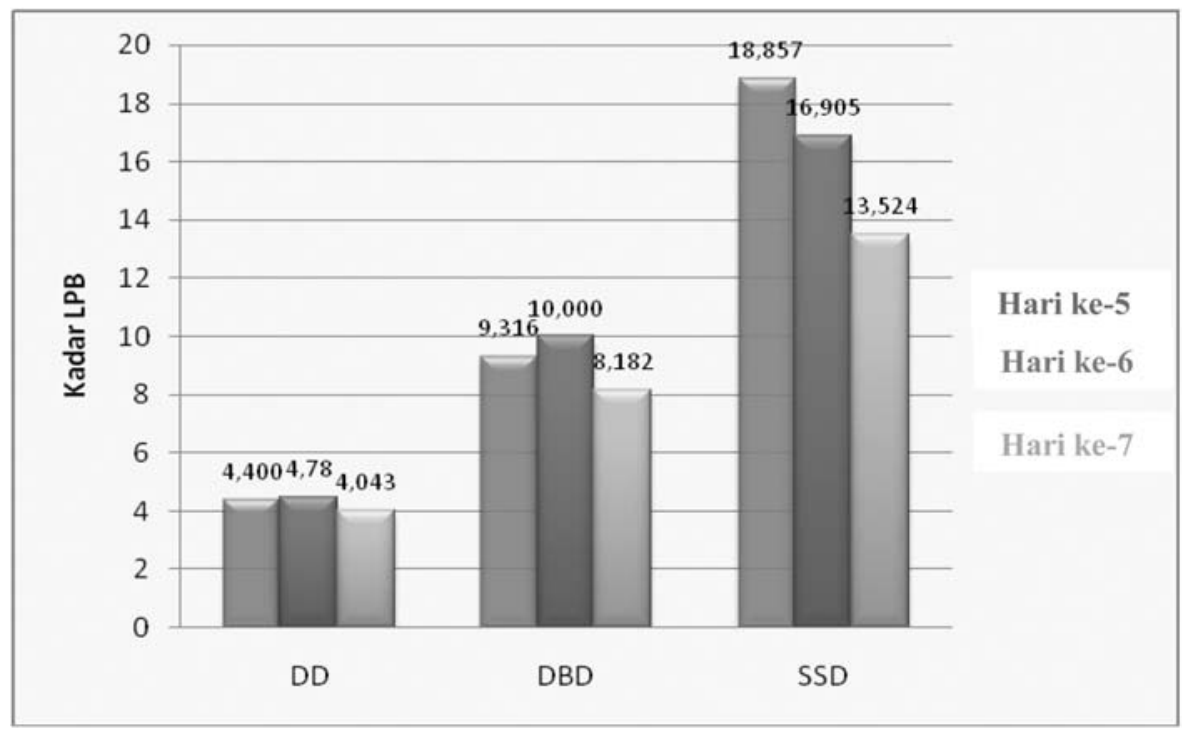

Gambar 1. Perbandingan jumlah LPB berdasar spektrum klinis 
dan 21 SSD. Selama periode penelitian 20 pasien DD menjadi DBD sehingga pada akhir penelitian terdapat 23 DD, 22 DBD, dan 21 SSD.

Jumlah rata-rata LPB pada pasien DD dan DBD mengalami puncak pada hari keenam sakit. Pasien SSD mempunyai jumlah LPB jauh lebih tinggi pada hari kelima sakit dibanding kedua spektrum klinis lainnya, dan mengalami penurunan pada hari keenam dan ketujuh sakit (Gambar 1). Berdasarkan uji ANOVA, didapat perbedaan bermakna rata-rata jumlah LPB di antara ketiga spektrum klinis $(p=0,000)$. Dapat diketahui bahwa pasangan DD dengan DBD memiliki perbedaan rata-rata jumlah LPB sebesar 4,1 dan perbedaan tersebut bermakna $(p=0,000)$, begitu juga untuk DD dengan SSD, DBD dengan DD dan SSD, dan SSD dengan DD dan DBD (Tabel 2).

Tabel 2. Perbedaan jumlah limfosit plasma biru di antara tipe klinis infeksi dengue

\begin{tabular}{cccc}
\hline $\begin{array}{c}\text { Spektrum } \\
\text { klinis } \\
\text { pembanding }\end{array}$ & $\begin{array}{c}\text { Spektrum } \\
\text { klinis yang } \\
\text { dibandingkan }\end{array}$ & $\begin{array}{c}\text { Perbedaan } \\
\text { jumlah rata- } \\
\text { rata LPB }\end{array}$ & $p$ \\
\hline DD & DBD & $-4,1$ & 0,000 \\
& SSD & $-9,5$ & 0,000 \\
DBD & DD & 4,1 & 0,000 \\
& SSD & $-5,3$ & 0,000 \\
SSD & DD & 9,5 & 0,000 \\
& DBD & 5,3 & 0,000 \\
\hline
\end{tabular}

Sebanyak 20 pasien DD mengalami perubahan tipe klinis menjadi DBD, sedangkan 23 anak tidak mengalami perubahan. Masing-masing memiliki nilai rata-rata rank jumlah LPB saat kedatangan 33,5 dan 12,02 yang berbeda secara bermakna $(p=0,000)$ dengan OR 2,096. Cut off point jumlah LPB yang dapat mengalami perubahan spektrum klinis menjadi DD adalah $\geq 6$ per 100 leukosit dengan sensitivitas dan spesifisitas yang cukup tinggi.

\section{Diskusi}

Spektrum klinis infeksi dengue bervariasi mulai dari yang asimtomatis sampai manifestasi berat dan fatal ditandai perdarahan dan syok. Pada penelitian prospektif, dari 66 anak yang masuk kriteria inklusi subjek penelitian dikelompokkan menjadi DD
$23(34,8 \%)$, DBD $22(33,3 \%)$, dan SSD 21 anak $(31,8 \%)$. Proporsi jenis kelamin laki-laki lebih banyak dibandingkan perempuan dengan rasio 1,4 : 1 . Umur terbanyak terdapat pada rentang umur 6-10 tahun (54,5\%). Uji Rumple Leede positif paling banyak dijumpai pada pasien demam berdarah dengue 33,3\%. Sedangkan uji Rumple Leede negatif paling banyak dijumpai pada pasien sindrom syok dengue 22,7\%. Pada DBD, hasil uji Rumple Leede positif dapat disebabkan karena virus dengue dapat menginfeksi sel endotel in vitro yang menyebabkan produksi sitokin dan kemokin yaitu IL-6, IL-8, dan RANTES. Sel endotel yang terinfeksi virus dengue dapat mengaktivasi komplemen dan mengaktivasi molekul adhesi seperti ICAM-1. Ekspresi dari ICAM-1 bersamaan dengan produksi sitokin IL-8 dan RANTES berturut-turut meningkatkan perlekatan sel polimorfonuklear dan sel mononuklear, serta mengakibatkan peningkatan vasopermeabilitas dan pelepasan trombomodulin. Pasien SSD sebagian besar menghasilkan uji Rumple Leede negatif, disebabkan karena pada pasien SSD telah terjadi penurunan volume plasma. . $^{7,811,16,17}$

Pasien SSD sebagian besar merupakan pasien yang mengalami infeksi sekunder (IgG positif dan IgM positif), 20 orang (30,3\%). Pada teori infeksi sekunder disebutkan apabila seseorang mendapat infeksi primer dengan satu jenis virus, akan terjadi kekebalan terhadap infeksi jenis virus tersebut dalam jangka waktu lama. Namun jika orang tersebut terinfeksi kembali dengan galur virus yang berbeda, akan terjadi infeksi berat. Dalam penelitian ini tidak diketahui jenis galur virus yang menginfeksi setiap pasien, namun dari beberapa penelitian dikemukakan infeksi sekunder oleh Den-2 umumnya akan bermanifestasi klinis lebih berat. Infeksi sekunder pada individu yang telah mempunyai antibodi heterolog merupakan kondisi kritis untuk terjadi DBD/SSD. ${ }^{8,18}$

Jumlah rata-rata LPB pada kelompok DD adalah 4,0 per 100 leukosit, DBD 8,2 per 100 leukosit, dan SSD 13,5 per 100 leukosit. Jumlah rata-rata LPB pada pasien DD dan DBD mengalami puncak pada hari keenam sakit. Hal ini sesuai dengan penelitian yang dilakukan oleh Sutaryo yang menemukan jumlah LPB mengalami puncak pada hari keenam. ${ }^{12}$ Pasien SSD mempunyai jumlah LPB tertinggi pada saat syok. Jumlah LPB untuk setiap tipe klinis memiliki perbedaan yang bermakna dan jumlah LPB semakin tinggi sesuai dengan beratnya spektrum klinis. Secara 
teoritis respons imunologi terhadap limfosit terjadi lebih besar pada DBD dibanding dengan DD. ${ }^{15} \mathrm{Hal}$ lain yang dapat menjelaskan mengapa jumlah LPB pada SSD jauh lebih tinggi daripada DBD karena pada SSD monosit yang terinfeksi virus lebih banyak yang mengakibatkan sel limfosit berdiferensiasi berubah menjadi limfosit atipik yang khas (LPB) menjadi lebih banyak. $^{7,15,18}$

Pada penelitian kami juga dapat diketahui bahwa jumlah LPB pasien DD pada saat kedatangan dapat menjadi prediktor tingkat keparahan penyakit karena pada pasien yang akhirnya mengalami DBD secara signifikan memiliki jumlah LPB saat kedatangan lebih tinggi dibandingkan dengan pasien yang tetap mengalami DD. Pada penelitian ini tidak ditemukan pasien yang diagnosis awalnya DD atau DBD kemudian berubah menjadi SSD namun pasien SSD pada saat datang semuanya dalam keadaan sedang syok atau telah mengalami syok berulang, hal ini mungkin disebabkan karena RS Hasan Sadikin merupakan rumah sakit rujukan di Provinsi Jawa Barat sehingga pasien yang dikirim dalam keadaan sakit berat.

Dengan ditemukannya odds ratio dan cut off point jumlah LPB dapat dipergunakan untuk mendeteksi perubahan spektrum klinis. Apabila pasien DD saat kedatangan mempunyai jumlah LPB $\geq 6$ per 100 leukosit maka pasien tersebut memiliki risiko dua kali lebih tinggi untuk mengalami perubahan menjadi DBD dibanding pasien DD yang memiliki LPB lebih rendah.

\section{Kesimpulan}

Limfosit plasma biru merupakan bentuk respons imun selular pada infeksi dengue, semakin berat respons imun yang terjadi maka semakin berat pula spektrum klinis yang dialami. Jumlah LPB pasien demam dengue pada saat kedatangan mempunyai peran dalam memprediksi perubahan spektrum klinis infeksi dengue. Bagi para klinisi pemeriksaan LPB pada anak yang mengalami infeksi dengue sebaiknya dilakukan pada semua spektrum klinis, yaitu pada saat pasien datang dan dilakukan secara periodik pada hari ke-5, ke-6, dan ke-7 sakit sehingga dapat dicegah terjadinya gejala klinis yang fatal, khususnya syok. Bila ditemukan jumlah LPB pasien DD pada saat kedatangan $\geq 6$ per 100 leukosit, hendaknya dilakukan pemantauan yang lebih ketat dan tindakan lebih agresif karena risiko untuk mengalami perubahan menjadi DBD lebih tinggi.

\section{Daftar Pustaka}

1. Sapir GD, Schimmer B. Dengue fever: new paradigms for a changing epidemiology. Emerg Them Epid. 2005;2:1-10.

2. World Health Organization. Dengue and dengue haemorrhagic fever-Factsheet. Geneva: WHO; 2002.

3. World Health Organization. Dengue fever in Indonesianupdate 2004.

4. Lin CF, Lei HY, Liu CC, Liu HS, Yeh TM, Chen SH. Autoimmunity in dengue virus infection. Dengue Bull. 2004;28:51-7.

5. WHO. Dengue, dengue haemorrhagic fever and dengue shock syndrome in the context of the integrated management of childhood illness. Geneva: WHO; 2005.

6. Gibbons RV, Vaughn DW. Dengue: an escalating problem. Brit Med J. 2002;324:1563-6.

7. Lei HY, Yeh TM, Liu HS, Lin YS, Chen SH, Ching CL. Immunopathogenesis of dengue virus infection. J Biomes Sci. 2001;8:377-88.

8. Sutaryo. Patogenesis dan patofisiologi demam berdarah dengue. Cermin Dunia Kedokteran. 1992;81:34-9.

9. World Health Organization. Dengue haemorrhagic fever: diagnosis, treatment, prevention and control. Edisi ke-2. Geneva: WHO; 1997.

10. Roitt I, Brostoff J, Male D. Immunology. Edisi ke-6. London: Mosby; 2001.

11. Guglani L, Kabra SK. T cell immunopathogenesis of dengue virus infection. Dengue Bull. 2005;29:58-69.

12. Sutaryo. Limfosit plasma biru, arti diagnostik dan sifat imunologik pada infeksi dengue. Tesis Doktor. Yogyakarta: Universitas Gadjah Mada; 1991.

13. Sumarmo PS. Demam berdarah dengue pada anak. Tesis. Jakarta: UI press; 1988.

14. Suvatte V, Longsaman M. Diagnostic value of buffy coat preparation in dengue hemorrhagic fever. Southeast Asian J Trop Med Public Health 1979;10:7-12.

15. Malavige GN, Fernando S, Fernando DJ, Seneviratne SL. Dengue viral infection. Postgrad Med J 2004;80:588-601.

16. Kurane I, Ennis FE. Immunity and immunopatology in dengue virus infection. Semin Immunol. 1992; 4:121-7.

17. Matheus S, Deparis X, Labeau B, Lelarge J, Morvan 
J, Dussart P. Discrimination between primary and secondary dengue virus infection by an immunoglobulin $\mathrm{G}$ avidity test using a single acute phase serum sample. J Clin Microbiol. 2005;43:2793-7.
18. Myint KS, Endy TP, Mongkolsirichaikul D, Manomuth, Kalayanarooj S, Vaughn DW. Cellular immune activation in children with acute dengue virus infections is modulated by apoptosis. J Inf Dis. 2006;194:600-7. 